\title{
Vegetative Response of Goldenweeds and Rayless Goldenrod to Simulated Mechanical Control
}

\author{
H.S. MAYEUX, JR.
}

Abstract

Topgrowth was clipped at heights which simulated mechanical disturbance from potted common goldenweed, Drummond's goldenweed, and rayless goldenrod plants in the glasshouse. Resprouting occurred within days after clipping at the soil surface or at heights of 2 to $8 \mathrm{~cm}$, but 50 to $100 \%$ of the plants clipped at the soil surface died within 5 to 10 weeks after treatment. No plants survived after topgrowth was removed at $2 \mathrm{~cm}$ below the soil surface. Mortality, numbers of adventitious sprouts on survivors, and stem elongation rates of regrowth varied little with species or phenological stage at treatment. Generally, topgrowth was completely replaced during the first growing season after clipping. Mechanical treatments which leave even small portions of rooted stems, such as shredding, roller chopping, or chaining, would not be effective against these undesirable subshrubs. Some control should be possible with blades such as the "stacker rake" which shears stems at ground level. Mechanical practices which sever the woody taproots at a shallow depth (discing or shallow root plowing) appear to be the most promising for control of these subshrubs.

The goldenweeds (Isocoma spp.) and rayless goldenrod ( $I$. Wrightii) are subshrubs which infest grasslands from the southern Texas coast [Drummond's goldenweed (I. Drummondii)] through the Rio Grande Plains [common goldenweed (I. coronopifolia)] to far West Texas, Arizona, and New Mexico (rayless goldenrod) (Correll and Johnston 1970). Common and Drummond's goldenweeds severely reduce forage production, and rayless goldenrod is highly poisonous to livestock (Sperry et al. 1965).

The feasibility of controlling these species with herbicides such as 2,4-D [(2,4-dichlorophenoxy) acetic acid] has been demonstrated, but responses to herbicide sprays are strongly dependent upon the occurrence of adequate rainfall to provide high availability of soil water prior to and during herbicide application (Mayeux et al. 1979, Mayeux and Scifres 1981, Sperry 1967). Use of herbicidal sprays in management of these subshrubs is limited by the low frequency of years with high rainfall during the growing season in the semiarid to arid regions where these species occur. Consequently, range managers have expressed interest in mechanical methods as alternatives to broadcast spraying.

Shredding of common goldenweed during March, April, May, or June was evaluated in a year of above-average rainfall on the Rio Grande Plains (Mayeux 1973). Because of adventitious sprouting, golden weed canopy cover increased within 1 yr to $143 \%$ of pretreatment levels. Similar changes in canopy cover were also observed where Drummond's goldenweed was shredded in summer, but no specific information is available concerning the regenerative abilities of these subshrubs.

The objective of this research was to determine the vegetative responses of the $\mathbf{3}$ goldenweed species to removal of topgrowth at

\footnotetext{
The author is range scientist, USDA-ARS, P.O. Box 748, Temple, Texas 76503. Technical assistance by R.A. Crane and Laura Leotta is gratefully acknowledged. Manuscript received July 6, 1981 .
}

heights representative of varying intensities of mechanical disturbance. Mortality was of major interest, but the ability of survivors to replace topgrowth was evaluated as an indication of clipping effects on subsequent vigor.

\section{Methods}

Plants of each goldenweed species were grown from seed in 25-cm diameter pots containing fine sandy loam soil ( $\mathrm{pH} 7.4)$. Each pot contained a single plant. All plants were in their second growing season, with basal stem dia meters of 1 to $2 \mathrm{~cm}$. Potted plants were maintained in a glasshouse where temperatures varied with time of day and season from 20 to $34^{\circ} \mathrm{C}$.

During July 1977, topgrowth was removed from potted Drummond's goldenweeds with pruning shears at heights of $1,2,4$, or 8 $\mathrm{cm}$ above the soil surface. Other plants of all three species were clipped during the early vegetative growth stage in April 1978. Topgrowth was removed by cutting the stems at $2 \mathrm{~cm}$ below the soil surface, at the soil surface, or at 2,4 , or $8 \mathrm{~cm}$ above the soil surface. The soil was temporarily removed from around the stem base and upper taproot and the taproot was clipped to sever the plants below the soil surface. Roots were disturbed as little as possible, but some fibrous surface roots were severed. The soil was replaced to cover the cut end of the woody taproot.

The same five treatments were applied to other plants of each species during full bloom in the fall. Because of inherent phenological differences among species in the timing of anthesis, topgrowth was removed from rayless goldenrod in early September, from common goldenweed in late October, and from Drummonds goldenweed in mid-November 1978. Plants with topgrowth left intact were included in each experiment. All plants were watered as needed and provided with half-strength Hoagland's solution weekly.

Plants were individually observed daily for 2 weeks and then weekly for 10 weeks after topgrowth removal and numbers of new vegetative buds were recorded. Plants which failed to resprout were considered dead, and death of plants which occurred after resprouting was also recorded. Canopy heights of Drummond's goldenweed clipped in July were recorded 120 days after treatment, whereas heights of rayless goldenrod, common goldenweed, and Drummond's goldenweed clipped in April were measured in September, approximately 150 days after treatment. Canopy heights of plants clipped in the fall 1978 were measured at 90 days after treatment and again in July 1979, approximately 130 to 190 days after clipping, depending upon species. Daily stem elongation rates of regrowth were calculated by dividing the difference between canopy heights at the beginning and end of the study period by the number of days elapsed.

Ten replicates (plants) of each species and clipping treatment were arranged in completely random designs. Untransformed mortality data by treatment (clipping height), season, and species was compared with chi-square tests without expected frequencies 
(Shefler 1969). Canopy heights and elongation rates by treatment or species were subjected to analysis of variance.

\section{Results and Discussion}

Goldenweed and rayless goldenrod plants clipped $2 \mathrm{~cm}$ below the soil surface did not resprout (Table 1). No evidence of bud initiation was found when the soil was carefully removed from around the taproots at the end of study. Essentially all plants of each species with topgrowth removed at or above the soil surface produced new vegetative buds on remaining stem tissues within 2 days after clipping, and new buds continued to appear for up to 5 weeks after clipping in April and throughout the winter and spring on plants clipped during full bloom. Plants clipped at the soil surface in April produced 2 to 10 buds; bud numbers increased with clipping height, with plants clipped at $8 \mathrm{~cm}$ bearing 51 to 80 buds. Numbers of buds produced by each species were similar (data not. shown).

All buds on most plants clipped at the soil surface and those on some plants clipped at a height of $2 \mathrm{~cm}$ died at 6 to 10 weeks after treatment. Eventual mortality of plants clipped at the soil surface ranged from $50 \%$ of Drummond's goldenweed clipped during full bloom to $100 \%$ of rayless goldenrod plants clipped in April (Table 1). Mortality of each species was 10 or $20 \%$ greater when clipped at the soil line during vegetative growth in spring than during full bloom in fall, but chi-square a nalysis indicated no statistical effect of season of treatment.

Mortality of rayless goldenrod and common goldenweed was only 20 to $30 \%$ at 10 weeks after clipping at a height of $2 \mathrm{~cm}$ in either spring or fall, and no Drummond's goldenweed were killed by this treatment (Table 1). Mortality of Drummond's goldenweed was consistently less than that of the other two species following top removal at the soil surfacc or at $2 \mathrm{~cm}$, although differences were slight ( 10 to $30 \%$ ) and not significant $\left(\chi^{2}=1.83\right)$. All Drummond's goldenweed plants survived clipping at heights from 1 to $8 \mathrm{~cm}$ in July. No mortality was observed after plants were clipped at 4 or 8 $\mathrm{cm}$ regardless of species or season (Table 1). Differences in mortality attributable to clipping height were highly significant $\left(\chi^{2}\right.$ $=89.3$ across all species).

Although adventitious buds appeared on stem bases within 2 days after clipping, elongation into stems did not begin until 2 to 3 weeks after topgrowth was removed in April or July. Initiation of stem growth on some plants clipped in the fall was delayed for up to 4 weeks.

Growth rates of Drummond's goldenweeds clipped in July varied little with clipping treatment. Average stem elongation rates ranged from $3.8 \mathrm{~mm} /$ day (1-cm clipping height) to $4.2 \mathrm{~mm} /$ day (4-cm clipping height) during the 120-day period of study. Calculated stem elongation rates ranged from 2.4 to $4.2 \mathrm{~mm} /$ day during the 5-month period after all 3 species were clipped in April (Table 2). Analysis of variance indicated no significant difference in growth rate attributable to species or clipping treatment, including untreated plants.

Table 1. Mortality of rayless goldenrod, common goldenweed, and Drummond's goldenweed 10 weeks after topgrowth was clipped above, at, or below the soil surface during vegetative growth in spring or full bloom in fall.

\begin{tabular}{|c|c|c|c|c|c|c|}
\hline \multirow[b]{3}{*}{ Clipping treatment } & \multicolumn{6}{|c|}{ Mortality $(\%)$ by species and season of treatment } \\
\hline & \multicolumn{2}{|c|}{$\begin{array}{c}\text { Rayless } \\
\text { goldenrod }\end{array}$} & \multicolumn{2}{|c|}{$\begin{array}{c}\text { Common } \\
\text { goldenweed }\end{array}$} & \multicolumn{2}{|c|}{$\begin{array}{c}\text { Drummond's } \\
\text { goldenweed }\end{array}$} \\
\hline & Spring & Fall & Spring & Fall & Spring & Fall \\
\hline None & $\mathbf{0}$ & $\mathbf{0}$ & 0 & 0 & 0 & 0 \\
\hline 4 or $8 \mathrm{~cm}$ height & 0 & $\mathbf{0}$ & 0 & 0 & 0 & 0 \\
\hline $2 \mathrm{~cm}$ height & 20 & 30 & 20 & 20 & 0 & 0 \\
\hline Soil surface & 100 & 80 & 80 & 70 & 70 & 50 \\
\hline $\begin{array}{l}2 \mathrm{~cm} \text { below soil } \\
\text { surface }\end{array}$ & 100 & 100 & 100 & 100 & 100 & 100 \\
\hline
\end{tabular}

Table 2. Mean stem elongation rates of adventitious sprouts during the 120-day period after topgrowth of rayless goldenrod, common goldenweed, and Drummond's goldenweed was clipped at various heights above the soil surface in spring.

\begin{tabular}{lccc}
\hline \hline & \multicolumn{2}{c}{ Stem elongation rate (mm/day \pm S.D.) by species } \\
\cline { 2 - 4 } Clipping treatment & $\begin{array}{c}\text { Rayless } \\
\text { golden }\end{array}$ & $\begin{array}{c}\text { Common } \\
\text { goldenweed }\end{array}$ & $\begin{array}{c}\text { Drummond's } \\
\text { goldenweed }\end{array}$ \\
\hline None & $2.4 \pm 0.3$ & $3.8 \pm 0.5$ & $3.6 \pm 0.7$ \\
$8 \mathrm{~cm}$ height & $2.7 \pm 0.3$ & $3.5 \pm 0.3$ & $2.8 \pm 0.9$ \\
$4 \mathrm{~cm}$ height & $3.1 \pm 0.5$ & $3.7 \pm 0.9$ & $3.1 \pm 0.3$ \\
$2 \mathrm{~cm}$ height & $3.1 \pm 0.9$ & $4.2 \pm 1.0$ & $3.4 \pm 0.7$ \\
\hline
\end{tabular}

IStem elongation re tes of plants clipped at the soil surface are not reported because too few survived to conititute an acceptable sample. Standard deviations were calculated from a sample size e, ual to the number of plants surviving each treatment. usually 10.

Canopy heights of rayless goldenrod and common goldenweed plants clipped in April were equal to those of untreated plants when measured in September (Table 3). Regardless of clipping height, Drummond's goldenweed regrowth did not attain heights equal to untreated plants during the first growing season after top removal. Heights of clipped plants ranged from 42 to $46 \mathrm{~cm}$ when measured in September, whereas untreated Drummond's goldenweeds averaged $59 \mathrm{~cm}$ in height (Table 3). Drummond's goldenweed plants clipped at 1 to $8 \mathrm{~cm}$ heights in July were 45 to $49 \mathrm{~cm}$ tall when measured last in November. Untreated plants had grown to an average height of $62 \mathrm{~cm}$.

Regrowth of plants which survived clipping during full bloom in the fall proceeded slowly during the winter months, averaging 0.8 to $1.1 \mathrm{~mm} /$ day, regardless of species or clipping height. Calculated growth rates during the period between the sampling at 90 days after clipping and the final sampling in July of the following yeas were comparable to those observed after clipping in April. Stem elongation rates of rayless goldenrod, common goldenweed, and Drummond's goldenweed averaged across all treatments were 2.1, 2.4 , and $2.4 \mathrm{~mm} /$ day, respectively, during the growing season following top removal in the fall. Growth rates did not vary significantly with species or clipping height. Similarly, no differences were seen in canopy heights when last measured in July, although heights of rayless goldenrod tended to be less than those of other species, as was noted after topgrowth was removed in the spring.

\section{Conclusions}

The three species of Isocoma readily tolerated topgrowth removal at all heights above the soil surface. Competition with forage species where any of these shrubs occur would be reduced for several months at most by mechanical treatments which leave some stem bases intact, such as shredding or roller chopping. The relatively high mortality of rayless golden rod $(100 \%)$ and common goldenweed (50-80\%) after clipping at the soil surface suggests that a shearing blade, such as the "stacking rake" commonly used in Texas for removal of woody brush (Fisher et al. 1973), should be evaluated for control of these subshrubs.

Tuble 3. Mean canopy height of rayless goldenrod, common goldenweed, and Drummond's goldenweed 5 months after topgrowth was clipped at various heights above the soil surface in April.

\begin{tabular}{lccc}
\hline \hline & \multicolumn{3}{c}{ Canopy height $(\mathrm{cm} \pm$ S.D.) by species } \\
\cline { 2 - 4 } Clipping treatment & $\begin{array}{c}\text { Rayless } \\
\text { goldenrod }\end{array}$ & $\begin{array}{c}\text { Common } \\
\text { goldenwood }\end{array}$ & $\begin{array}{c}\text { Dummond's } \\
\text { goldenweed }\end{array}$ \\
\hline None & $40 \pm 4$ & $58 \pm 7$ & $59 \pm 9$ \\
$8 \mathrm{~cm}$ height & $43 \pm 4$ & $54 \pm 4$ & $45 \pm 12$ \\
$4 \mathrm{~cm}$ height & $45 \pm 7$ & $52 \pm 12$ & $45 \pm 4$ \\
$2 \mathrm{~cm}$ height & $43 \pm 12$ & $57 \pm 12$ & $46 \pm 8$ \\
\hline
\end{tabular}

'Canopy heights of plants clipped at the soil surface were not reported because too few survived to constitute an acceptable sample. Standard deviations were calculated from a sample size equal to the number of plants surviving each treatment, usually 10 . 
Based on their response in the glasshouse, complete control would be expected with mechanical practices which sever the plants below the soil surface. Discing offers excellent potential for control of these small shrubs because it effectively severs roots at depths of 5 to $10 \mathrm{~cm}$, and discing prepares a seedbed for revegetation. Encouraging results have recently been obtained by shallow rootplowing to a maximum depth of $20 \mathrm{~cm}$ during the dry summer months (personal communication, E.E. Martinez, County Extension Agent, Zapata County, Tex.); rootplowing at depths recommended for control of wood brush species, 25 to $40 \mathrm{~cm}$ (Fisher et al. 1973), is apparently ineffective against rayless goldenrod and the goldenweeds. Use of both discing and shallow rootplowing may be limited by the presence of the larger woody brush plants which commonly occur in association with the shrubs.

Rayless goldenrod and common goldenweed responded similarly to topgrowth removal during early vegetative growth in spring or during full bloom in fall, and the response of Drummond's goldenweed differed little in spring, mid-summer, or fall. The effectiveness of mechanical control practices is apparently not dependent upon phenological stage at the time of treatment.

In this study, clipping had no apparent adverse effect on the plants not killed. A single clipping did not reduce vigor as measured by growth rates or numbers of buds producing adventitious stems. Usually, topgrowth was completely replaced during the season of treatment or during the following season if plants were clipped at the end of the growing season.

\section{Literature Cited}

Correll, D., and M.C. Johnston. 1970. Manual of the Vascular Plants of Texas. Tex. Res. Found., Renner. 1881 p.

Fisher, C.E., H.T. Wiedemann, C.H. Meadors, and J.H. Brock. 1973. Mechanical control of mesquite. Pages 46-52. In: Mesquite, Tex. Agr. Exp. Sta. Res. Monograph 1.

Mayeux, H.S., Jr. 1973. Chemical control of goldenweed [Isocoma coronopifolia (Gray) Greene]. M.S. Thesis, Texas A\&I University, Kingsville. $83 \mathrm{p}$.

Mayeu x, H.S., Jr., D.L. Drawe, and C.J.Scifres. 1979. Control of common goldenweed with herbicides and associated forage release. J. Range Manage. 32.271-274.

Mayeux, H.S., Jr., and C.J. Scifres. 1981. Drummond's gold enweed and its control with herbicides. J. Range Manage. 34:98-101.

Shefler, W.C. 1969. Statistics for the Biological Sciences. Addison-Wesley, Reading, Mass. 231 p.

Sperry, O.E. 1967. Experimental studies on the control of rayless goldenrod and perennial broomweed. Tex. Agr. Exp. Sta. Prog. Rep. 2456. 6p.

Sperry, O.E., J.W. Dollahite, G.O. Hoffman, and B.J. Camp. 1965. Texas plants poisonous to livestock. Tex. Agr. Exp. Sta. B-2128. 57 p.

Temporary Position: The Range Science Department at Colorado State University has an open teaching and research position available for a range animal ecologist. Emphasis in teaching will be on consumer function in range ecosystems, habitat manipulations, and principles of range management. The research program will depend upon the individual's specific interest. The appointment is a nine-month, nontenure track position with possible opportunity for additional employment during the three (3) summer months. The position is for two academic years.

Qualifications: Ph.D. degree or equivalent experience required with specialization in Range Science or closely related field.

Salary and Rank: Salary and rank will be commensurate with qualifications of the individual appointed. Starting date not later than 20 August 1983.

Application: Applicants should send a letter of application, a curriculum vitae, list of publications, list of research projects conducted or directed, courses previously taught, a resume of professional experience, and names, addresses, and telephone numbers of at least three individuals familiar with the candidate's professional competence. For applicants with less than three (3) years' experience, transcripts should be included.

Completed applications must be received by the Search Committee by 10 March 1983. Applications may be made to: Dr. M.J. Trlica, Chairperson of the Search Committee, Range Science Department, Colorado State University, Fort Collins, Colorado 80523.

CSU is EEO/AA employer. E.O. Office: 314 Student Services Building. 